\title{
Preparation of Antitumor Active Vinyl Polymers Containing 5-Fluorouracil as a Component ${ }^{\dagger}$
}

\author{
Shoichiro Ozaki, ${ }^{\dagger \dagger}$ Junji OHNISHI, Takahiko AkIYAMA, \\ Toshio Nagase, Nobuaki Uehara,* \\ and Akio HosHI* \\ Department of Resources of Chemistry, Faculty of Engineering, \\ Ehime University, Bunkyo-cho, \\ Matsuyama 790, Japan \\ * National Cancer Center Research Institute, Tsukiji, Chuo-ku, \\ Tokyo 104, Japan
}

(Received January 24, 1990)

\begin{abstract}
Acryloyloxyethylcarbamoyl-5-fluorouracil (1) was prepared by the reaction of 5-fluorouracil and 1-acryloyloxyethyl isocyanate. Various kinds of vinyl polymers were prepared by radical polymerizations of 1 , with methyl acrylate, vinylimidazole, acrylic acid, vinylpyrrolidone, and acrylamide. Antitumor activity of these vinyl polymers was tested against L-1210 leukemia in mice. 1 had toxicity, but the homopolymer of 1 and the copolymer of 1 and methyl acrylate showed excellent antitumor activity.

KEY WORDS Vinyl Polymer / Copolymer / Radical Polymerization / Polymeric Drug / Antitumor Agent / 5-Fluorouracil /
\end{abstract}

5-Fluorouracil (5-FU) have antitumor activity and is in clinical use. In order to improve antitumor activity and pharmacological properties of 5-FU, various kinds of 5-FU derivatives were synthesized and their antitumor activity was investigated. In our laboratory, to develop antitumor agents with high antitumor activity and low toxicity, we have synthesized various kinds of 5-FU derivatives, such as 1-carbamoyll-, ${ }^{2} 1$-acyloxyalkyl-, ${ }^{3}$ 1-alkylthiocarbamoyl-, 4 1-alkoxyalkyl-, ${ }^{5}$ 5-fluorouracils so on. Among which, 1-carbamoyl-5-fluorouracils were found to be stable in acidic media and to decompose at the moderate rate in neutral media and showed excellent antitumor activity owing to the proper hydrolytic ratio of $N$-carbamoyl function in vivo to release 5-FU. Consequently, 1hexylcarbamoyl-5-fluorouracil (HCFU) is re- markably effective in colorectal, lung, breast, and gastric cancers and is in clinical use in Japan. ${ }^{6}$ But its side effects, such as hot sensation and pollakiuria syndrome prompted us to search a superior compound as an antitumor agent. Recently, functional polymers containing 5-FU have attracted considerable attention from the standpoint of polymeric drugs. ${ }^{6}$ Polymeric drugs are expected to have slow release function, and to become long acting agents with reduced toxicity. We supposed that functional polymers linked to 5-FU through appropriately labile function would become excellent antitumor agents as masked 5-fluorouracil derivatives. In a previous paper, ${ }^{8}$ we have reported that vinyl polymers having 5-FU which attach to the main chain through carbonyloxymethyl group showed higher antitumor activity. This time we

† 5-Fluorouracil Derivatives. Part XIX. For Part XVIII of this series, see ref 1.

${ }^{\dagger \dagger}$ To whom all correspondence should be addressed. 
synthesized vinyl polymers linked to 5-FU through $N$-carbamoyl group, which would be hydrolyzed slowly to release 5-FU in vivo. We wish to report here the preparation of vinyl polymers having 5-FU attaching to the main chain through carbonyloxyethylcarbamoyl group and antitumor activity of them.

\section{EXPERIMENTAL}

\section{Materials}

Monomer Synthesis. 3-Chloropropionyloxyethyl isocyanate (4). 3-Chloropropionyl chloride $(19.6 \mathrm{ml}, 0.205 \mathrm{~mol})$ was added to a toluene solution $(50 \mathrm{ml})$ of ethanolamine hydrochloride $(18.0 \mathrm{~g}, \quad 0.185 \mathrm{~mol})$ at 90 $100^{\circ} \mathrm{C}$. After stirring at that temperature for $2.5 \mathrm{~h}$, the mixture was cooled to room temperature. Phosgene dimer $(20 \mathrm{ml}, 0.17 \mathrm{~mol})$ was added to the mixture, and the mixture was slowly heated to $100^{\circ} \mathrm{C}$. The solution turned yellow. Phosgene gas, generated from phosgene dimer $(20 \mathrm{ml}, 0.17 \mathrm{~mol})$, was bubbled into the solution, during which time the yellow solution turned clean. $\mathrm{N}_{2}$ gas was bubbled into the solution to exclude excess phosgene gas. Solvent was evaporated under reduced pressure and the residue was distilled to obtain 3-chloropropionyloxyethyl isocyanate (4) in $79 \%$ yield $(25.9 \mathrm{~g})$. bp $112-115^{\circ} \mathrm{C} / 5.0 \mathrm{mmHg}$. IR (neat, $\mathrm{cm}^{-1}$ ): 2250 (NCO) and 1730 (COO). ${ }^{1} \mathrm{H}$ NMR $\left(60 \mathrm{MHz}, \mathrm{CDCl}_{3}\right) \delta: 2.80(\mathrm{t}, 2 \mathrm{H}$, $J=5 \mathrm{~Hz}), 3.60(\mathrm{t}, 2 \mathrm{H}, J=5 \mathrm{~Hz}), 3.70 \quad(\mathrm{t}$, $J=5 \mathrm{~Hz}), 4.25(\mathrm{t}, 2 \mathrm{H}, J=5 \mathrm{~Hz})$.

Acryloyloxyethyl Isocyanate (5). A mixture of 3-chloropropionyloxyethyl isocyanate (4) $(25.8 \mathrm{~g}, 0.145 \mathrm{~mol})$, quinoline $(17.4 \mathrm{ml}$, $0.148 \mathrm{~mol})$, and anthraquinone $(232 \mathrm{mg}, 1.16$ mmol) was heated to $160^{\circ} \mathrm{C}$ for $2 \mathrm{~h}$ under $\mathrm{N}_{2}$ atmosphere. Distillation of the mixture under reduced pressure gave acryloyloxyethyl isocyanate $(5)$ in $70 \%$ yield $(14.3 \mathrm{~g})$. bp $78-82^{\circ} \mathrm{C} /$ $10 \mathrm{mmHg}$. IR (neat, $\mathrm{cm}^{-1}$ ): 2220 (NCO) and 1720 (COO). ${ }^{1} \mathrm{H}$ NMR (60 MHz, $\left.\mathrm{CCl}_{4}\right) \delta: 3.50$ $\left(\mathrm{t}, 2 \mathrm{H}, J=5 \mathrm{~Hz}, \mathrm{CH}_{2} \mathrm{NCO}\right), 4.25(\mathrm{t}, 2 \mathrm{H}$, $\left.J=5 \mathrm{~Hz}, \mathrm{CO}_{2} \mathrm{CH}_{2}\right)$, and $5.75-6.60(\mathrm{~m}, 3 \mathrm{H}$, vinyl).

1-Acryloyloxyethylcarbamoyl-5-fluorouracil (1). A mixture of 5 -FU $(55.2 \mathrm{mg}, 0.425$ mmol) and acryloyloxyethyl isocyanate (5) $(60 \mathrm{mg}, 0.425 \mathrm{mmol})$ was allowed to react in pyridine $(0.5 \mathrm{ml})$ in the presence of cat. amount of hydroquinone under $\mathrm{N}_{2}$ atmosphere at room temperature for $3 \mathrm{~h}$. The solvent was removed under reduced pressure, $1 \mathrm{~N} \mathrm{HCl}$ was added to the residue. The mixture was extracted with ethyl acetate and the organic layer was dried over anhydrous $\mathrm{MgSO}_{4}$, evaporated to dryness to leave an oil. The residue was recrystallized from a mixture of ethyl acetate and hexane to obtain 1-acryloyloxyethylcarbamoyl-5-fluorouracil (1) in $79 \%$ yield $(90.8 \mathrm{mg}) ; \mathrm{mp}$ $140-142^{\circ} \mathrm{C}$. IR (nujol, $\mathrm{cm}^{-1}$ ): 3330,1730 , and 1690. ${ }^{1} \mathrm{H}$ NMR $\left(100 \mathrm{MHz}, \mathrm{DMSO}-d_{6}\right.$ and $\left.\mathrm{CDCl}_{3}\right) \delta: 3.66\left(\mathrm{q}, 2 \mathrm{H}, J=6 \mathrm{~Hz}, \mathrm{CH}_{2} \mathrm{~N}\right), 4.28$ $\left(\mathrm{t}, 2 \mathrm{H}, J=6 \mathrm{~Hz}, \mathrm{COOCH}_{2}\right), 5.76-6.50(\mathrm{~m}, 3 \mathrm{H}$, vinyl), 8.40 (d, $1 \mathrm{H}, J=7 \mathrm{~Hz}, \mathrm{H6}$ ), 9.44 (br s, 1H, NHCO), 12.30 (br s, 1H, H3). Anal. Calcd for $\mathrm{C}_{10} \mathrm{H}_{10} \mathrm{O}_{5} \mathrm{~N}_{3} \mathrm{~F}: \mathrm{C}, 44.29 \% ; \mathrm{H}, 3.72 \%$ : N, $15.49 \%$. Found: C, $44.21 \%$; H, 3.67\%; N, $15.79 \%$.

\section{Polymer Synthesis}

Solvent. Benzene was distilled over $\mathrm{CaH}_{2}$ and was degassed at reduced pressure with being freezed at $-78^{\circ} \mathrm{C}$, followed by bubbling $\mathrm{N}_{2}$ gas into the solution at room temperature for an hour. Other solvents used in polymerization were dried as usual manner and were degassed by bubbling $\mathrm{N}_{2}$ gas into the solvent at room temperature for an hour.

Homopolymer of 1 . Screening of solvent; a mixture of 1-acryloyloxyethylcarbamoyl-5fluorouracil (1) and azobisisobutyronitrile (AIBN) were dissolved in the following solution and heated under $\mathrm{N}_{2}$ atmosphere. Elimination of 5-FU was monitored with silica gel thin layer chromatography (TLC). $\mathrm{MeOH}$ was added to the reaction mixture and the precipitate thus formed was taken by filtration.

1) $1(66.2 \mathrm{mg}, 0.244 \mathrm{mmol})$ and AIBN $(2.5 \mathrm{mg}, 0.015 \mathrm{mmol})$ in benzene $(3 \mathrm{ml})$ were 
heated at $60^{\circ} \mathrm{C}$ for $15 \mathrm{~h}$. No precipitates were found after addition of methanol $(3 \mathrm{ml})$.

2) $1(15.5 \mathrm{mg}, 0.0572 \mathrm{mmol})$ and AIBN ( $2.5 \mathrm{mg}, 0.015 \mathrm{mmol})$ in $\mathrm{CH}_{3} \mathrm{CN}(1.0 \mathrm{ml})$ were refluxed. After $15 \mathrm{~h}$, methanol $(4 \mathrm{ml})$ was added and no formation of the precipitate was found.

3) $1(214 \mathrm{mg}, 0.790 \mathrm{mmol})$ and AIBN $(6.3 \mathrm{mg}, 0.038 \mathrm{mmol})$ in DMF $(10 \mathrm{ml})$ were heated at $45^{\circ} \mathrm{C}$ for $6 \mathrm{~h}$ and then at $75^{\circ} \mathrm{C}$ for $3.5 \mathrm{~h}$. Starting material and a large amount of 5-FU were observed with TLC analysis.

4) 1 (33.6 mg, $0.124 \mathrm{mmol})$ and AIBN $(5.0 \mathrm{mg}, 0.03 \mathrm{mmol})$ in THF $(3 \mathrm{ml})$ were heated to $70^{\circ} \mathrm{C}$ for $7 \mathrm{~h}$. The precipitate was observed in the reaction mixture. At the same time 5-FU was also observed with TLC analysis.

5) 1 (74.8 $\mathrm{mg}, 0.276 \mathrm{mmol})$ and AIBN $(2.4 \mathrm{mg}, 0.015 \mathrm{mmol})$ in methanol $(7 \mathrm{ml})$ were refluxed for $7.5 \mathrm{~h}$. Starting material almost disappeared and precipitate was formed but a large amount of 5-FU was observed with TLC.

6) $1(19.2 \mathrm{mg}, 0.0708 \mathrm{mmol})$ and AIBN (2.0 mmol, $0.012 \mathrm{mmol}$ ) in $\mathrm{CH}_{2} \mathrm{Cl}_{2}(4 \mathrm{ml})$ were heated to reflux for $4.5 \mathrm{~h}$. Formation of the polymer was observed and no 5-FU was detected with TLC.

Poly (1-acryloyloxyethylcarbamoyl-5-fluorouracil) (2). 1-Acryloyloxyethylcarbamoyl-5fluorouracil (1) $(2.07 \mathrm{~g}, 7.64 \mathrm{mmol})$ and azobisisobutyronitrile (AIBN) $(69 \mathrm{mg}, 0.421 \mathrm{mmol})$ were dissolved in $\mathrm{CH}_{2} \mathrm{Cl}_{2}(60 \mathrm{ml})$ and refluxed under $\mathrm{N}_{2}$ atmosphere for $15 \mathrm{~h}$. The precipitates thus formed were collected by filtration and washed with $\mathrm{CH}_{3} \mathrm{OH}$ to obtain poly(1acryloyloxyethylcarbamoyl-5-fluorouracil) (2) as a white solid in $18 \%$ yield $(378 \mathrm{mg}) ; \mathrm{mp}$ $230^{\circ} \mathrm{C}$ (dec.) Anal. Calcd for $\mathrm{C}_{10} \mathrm{H}_{10} \mathrm{O}_{5} \mathrm{~N}_{3} \mathrm{~F}$ : C, $44.29 \%$; H, 3.72\%; N, 15.49\%. Found: C, $43.96 \%$; H, 3.80\%, N; $15.52 \%$.

Copolymer of 1 and Methyl Acrylate (3a) 1-Acryloyloxyethylcarbamoyl-5-fluorouracil (1) $(1.50 \mathrm{~g}, 5.54 \mathrm{mmol})$ and methyl acrylate $(1.00 \mathrm{ml}, 11.1 \mathrm{mmol})$ were refluxed in $\mathrm{CH}_{2} \mathrm{Cl}_{2}(60 \mathrm{ml})$ in the presence of AIBN $(135 \mathrm{mg})$ for $10 \mathrm{~h}$. The solvent was evaporated under reduced pressure to leave an oil, and
$\mathrm{CH}_{3} \mathrm{OH}(350 \mathrm{ml})$ was added. The precipitate thus formed was collected and washed with $\mathrm{CH}_{3} \mathrm{OH}(30 \mathrm{ml} \times 4)$ to give $3 \mathrm{a}$ as a crystal; $\mathrm{mp} 230^{\circ} \mathrm{C}$ (dec.) Anal. Found: C, $46.51 \%$; $\mathrm{H}, 4.37 \%$; N, $10.38 \%$. The composition ratio was calculated based on this elemental analysis data. $(\mathrm{m}: \mathrm{n}=44: 56)$.

Copolymer of 1 and Vinylimidazole (3b). $\quad 3 \mathrm{~b}$ (307 $\mathrm{mg}$ ) was prepared according to the method described above starting from 1 (389 $\mathrm{mg}$, $1.43 \mathrm{mmol})$ and vinylimidazole $(909 \mathrm{ml}, 10.0$ mmol) and AIBN (128 mg) in $\mathrm{CH}_{2} \mathrm{Cl}_{2}(63 \mathrm{ml})$, mp $200-210^{\circ} \mathrm{C}$ (dec.) Anal. Found: C, $47.85 \%$; $\mathrm{H}, 4.26 \%$; N, $18.91 \% . \mathrm{m}: \mathrm{n}=47: 53$.

Copolymer of 1 and Acrylic Acid (3c). 3c $(332 \mathrm{mg})$ was obtained in the same manner starting from $1(800 \mathrm{mg}, 2.95 \mathrm{mmol})$ and acrylic acid $(101 \mathrm{ml}, 1.48 \mathrm{mmol})$ and AIBN $(36.4 \mathrm{mg})$ in $\mathrm{CH}_{2} \mathrm{Cl}_{2}(18 \mathrm{ml})$ as a crystal. Anal. Found: C, $44.73 \%$; H, $4.20 \%$; N, $11.77 \%$. $m: n=52$ : 48.

Copolymer of 1 and Vinylpyrrolidone (3d). 3d $(533 \mathrm{mg})$ was prepared according to the same method described above starting from 1 (400 mg, $1.48 \mathrm{mmol}$ ) and vinylpyrrolidone $(0.50 \mathrm{ml}, 4.43 \mathrm{mmol})$ and AIBN $(48.5 \mathrm{mg})$ in $\mathrm{CH}_{2} \mathrm{Cl}_{2}(24 \mathrm{ml})$ for $8 \mathrm{~h}$, Anal. Found: C, $49.45 \% ; \mathrm{H}, 4.96 \% ; \mathrm{N}, 13.80 \%$. $\mathrm{m}: \mathrm{n}=49: 51$.

Copolymer of 1 and Acrylamide (3e). $3 \mathbf{e}$ (506 $\mathrm{mg})$ was synthesized starting from 1 $(900 \mathrm{mg}, 3.32 \mathrm{~mol})$ and acrylamide $(118 \mathrm{mg}$, $1.66 \mathrm{mmol})$ and AIBN (40.8 mg) in $\mathrm{CH}_{2} \mathrm{Cl}_{2}$ $(20 \mathrm{ml})$ for $4 \mathrm{~h}$. Anal. Found: C, $44.45 \% ; \mathrm{H}$, $4.46 \% ; \mathrm{N}, 15.58 \% . \mathrm{m}: \mathrm{n}=55: 45$.

\section{Instrumentation}

Melting points were determined on a Yamato melting point apparatus and are uncorrected. Infrared (IR) spectra were taken on a Hitachi EPI-G3 spectrometer. Proton nuclear magnetic resonance $\left({ }^{1} \mathrm{H}\right.$ NMR $)$ spectra were recorded on a JEOL JNM FX-100S or Hitachi R-20 with tetramethylsilane as an internal standard. 
Animals and Tumor System

Male $\mathrm{BDF}_{1}$ mice weighing $20 \pm 2 \mathrm{~g}$ were used. Six mice in each group, either test or control, were implanted intraperitoneally with $1 \times 10^{5}$ L-1210 leukemia cells. The compound to be tested was injected intraperitoneally once daily for 5 days, starting $24 \mathrm{~h}$ after tumor implantation.

\section{Evaluation of Antitumor Activity}

The increase in life span was calculated by using the following formula:

$$
\begin{gathered}
\text { ILS (increase in life span) }(\%) \\
=(T-C) / C \times 100
\end{gathered}
$$

where $T$ is the average number of days before death in the test group and $C$ is the average number of days before death in the control group. ${ }^{9}$

\section{RESULTS AND DISCUSSION}

\section{Monomer Synthesis}

1-Acryloyloxyethylcarbamoyl-5-fluorouracil (1) was prepared starting from 3-chloropropionyl chloride as shown in scheme 1 . 3-Chloropropionyl chloride and ethanolamine hydrochloride were treated with phosgene gas to give 3-chloropropionyloxyethyl isocyanate
(4), a new compound, followed by dehydrochlorination by use of quinoline as a base to give labile acryloyloxyethyl isocyanate (5) as an oil. The newly synthesized isocyanate was allowed to react with 5-FU in pyridine at room temperature to give 1-acryloyloxyethylcarbamoyl-5-fluorouracil (1) as a crystal in $79 \%$ yield.

\section{Homopolymerization of $\mathbf{1}$}

We attempted a radical polymerization of $\mathbf{1}$, a newly synthesized vinyl monomer, using AIBN as an initiator in benzene at $60^{\circ} \mathrm{C}$ for $15 \mathrm{~h}$, and no formation of precipitates was observed after the addition of $\mathrm{MeOH}$ to the reaction mixture, which implies $\mathrm{MeOH}$ soluble low molecular oligomer of 1 might be formed, although, high molecular polymer was not

Table I. Screening of solvent

\begin{tabular}{ccccc}
\hline Run & Solvent & $\begin{array}{c}\text { Reaction } \\
\text { time (h) }\end{array}$ & $\begin{array}{c}\text { Release } \\
\text { of 5-FU }\end{array}$ & $\begin{array}{c}\text { Formation } \\
\text { of polymer }\end{array}$ \\
\hline 1 & Benzene & 15 & - & - \\
2 & Acetonitrile & 15 & - & - \\
3 & DMF & 9.5 & + & - \\
4 & THF & 5 & + & + \\
5 & $\mathrm{Methanol}_{6}$ & 7.5 & + & + \\
$\mathrm{CH}_{2} \mathrm{Cl}_{2}$ & 15 & - & $+(18 \%)$ \\
\hline
\end{tabular}

Reaction conditions, see the text.<smiles>O=C(Cl)CCCl</smiles><smiles>C=CC(=O)OCC[N+](=O)[O-]</smiles>

5<smiles>C=CC(=O)OCCNC(=O)n1cc(F)c(=O)[nH]c1=O</smiles>

1

Scheme 1. 
formed under the reaction conditions. We therefore tried radical polymerizations of 1 in various solvents as shown in Table 1 . When $\mathrm{CH}_{3} \mathrm{CN}$ of DMF were used as solvents, precipitates were not observed neither, and elimination of 5-FU was observed with TLC analysis in the case of DMF. Next the polymerizations were carried out in tetrahydrofuran (THF) or $\mathrm{CH}_{3} \mathrm{OH}$ as solvents to obtain the homopolymer (2), but a large amount of 5-FU was also detected by TLC analyses. We are not sure whether 5-FU was released directly from 1 or from the formed homopolymer, but it is certain that this carbamoyl function is not stable under these reaction conditions. When the polymerization was carried out in refluxing $\mathrm{CH}_{2} \mathrm{Cl}_{2}$ with AIBN as an initiator, formation of precipitates was observed. After $15 \mathrm{~h}, \mathrm{MeOH}$ was added to the reactionn mixture at room temperature and the solid was taken by filtration and was identified as poly(1-acryloyloxyethylcarbamoyl-5fluorouracil) (2), the homopolymer of 1 , by elemental analyses. The yield was $18 \%$. This was the only case no elimination of 5-FU was observed by TLC analysis in the reaction conditions we tried.

\section{Copolymerization with Other Monomers}

Based on the above results, copolymerizations of 1 and other monomes were carried out in refluxing $\mathrm{CH}_{2} \mathrm{Cl}_{2}$ with $\mathrm{AIBN}$ as an initiator. To investigate the effect of the side chain on the antitumor activity, we wished to obtain copolymers with a composition ratio close to $1: 1$. At first a copolymer of 1 and methyl acrylate was prepared. The molar ratio of the starting material was changed from 0.2 to 3 as

Table II. Results of polymerization of $\mathbf{1}$

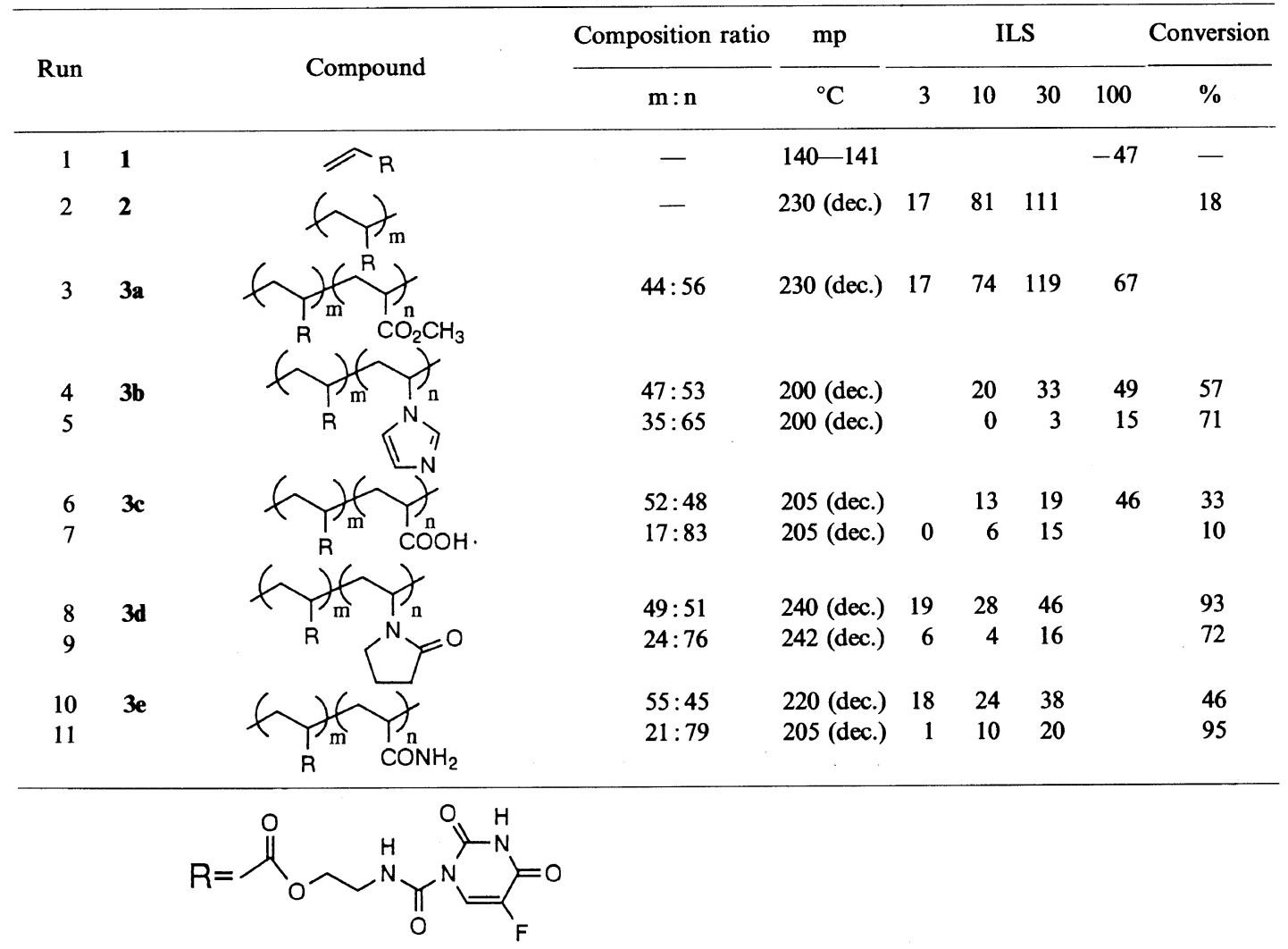


shown in Table II so as to obtain copolymers with the composition ratio close to $1: 1$. The composition ratio of the copolymer was calculated based on the elemental analyses data of the obtained copolymer. When 1 and methyl acrylate were allowed to react in the molar ratio $1: 2$, the composition ratio of the obtained copolymer got close to $1: 1$. Methyl methacrylate, vinylimidazole, acrylic acid, vinylpyrrolidone, and acrylamide were also used as monomers. In these cases, the ratio of the starting materials were changed to obtain copolymers with the composition ratio close to $1: 1$. Monomer reactivity ratio of copolymer 3c was calculated according to the Finemann-Ross method $(r(1)=0.14, \quad r($ acrylic acid) $=0.36$ )

\section{Antitumor Activity}

The antitumor activity of the obtained<smiles>O=c1[nH]cc(F)c(=O)[nH]1</smiles>

$$
\text { 5-FU }
$$<smiles>C=CC(=O)OCCNC(=O)n1cc(F)c(=O)[nH]c1=O</smiles>

1
Table III. Reactivity ratio 1 and various monomers

\begin{tabular}{|c|c|c|c|}
\hline Run & Monomer & $r_{1}$ & $r_{2}$ \\
\hline 1 & & 1.15 & 0.209 \\
\hline 2 & & 0.43 & 0.68 \\
\hline 3 & & 2.03 & 0.112 \\
\hline 4 & & 0.140 & 0.355 \\
\hline 5 & & 2.03 & 0.133 \\
\hline 6 & & 0.314 & 0.668 \\
\hline
\end{tabular}

$r_{1}, r_{2}=$ monomer reactivity ratio.

HCFU<smiles>CC(C)(C)CC(C(=O)OCCNC(=O)n1cc(F)c(=O)[nH]c1=O)C(C)(C)C</smiles>

2<smiles>[Y]C(C)CC(C)C(CCC)C(=O)OCCNC(=O)n1cc(F)c(=O)[nH]c1=O</smiles> 
compounds was tested against L-1210 leukemia by intraperitoneal administration in mice, and the ILS (increase in life span) values are shown in Table II. Copolymers with the composition ratio close to $1: 1$ were used as screening samples. Although the monomer 1 showed negative value, toxicity, the hommopolymer 2 showed large ILS value, indicating high antitumor activity. Copolymer with methylmethacrylate monomer 3a in the polymer chain showed large ILS value too. Other polymers also showed moderate antitumor activity. It is noteworthy that monomer itself is toxic whereas the corresponding polymer has excellent antitumor activity. This result suggests that the polymers 2 and 3 would be hydrolyzed more slowly than the monomer 1 itself to release 5-FU and showed high antitumor activity for long hours and that 1 and $\mathbf{2}$ are potent polymeric antitumor agents. Further screening test against other tumor systems are in progress in our laboratories.

\section{CONCLUSION}

1-Acryloyloxyethylcarbamoyl-5-fluorouracil (1) was synthesized as a new vinyl monomer containing 5-FU and, the homopolymer (2) and the copolymers (3) were prepared by radical polymerizations. The antitumor activity was tested against L-1210 leukemia in mice. The homopolymer (2) and the copolymers having methyl acrylate as the polymer chain (3a) showed excellent antitumor activity. Other copolymers also showed moderate antitumor activity, whereas monomer (1) showed toxicity. Moderate to high antitumor activity of these polymers contrast clearly with the toxicity of the monomer itself. Many anticancer drugs have been developed thus far, but toxicity of them is a crucial problem, and antitumor drugs with less toxicity are desirable. The polymeric drug is one of the solution to the problem now. The homopolymer $2 \mathbf{a}$ and the copolymer $3 \mathbf{a}$ are promising agents in terms of the above consideration.

Acknowledgments. The authors wish to thank the Advanced Center for Chemical Analysis, Ehime University, for elemental analysis.

\section{REFERENCES}

1. T. Akiyama, M. Kumegawa, Y. Takesue, H. Nishimoto, and S. Ozaki, Chem. Lett., 339 (1990).

2. S. Ozaki, Y. Ike, H. Mizuno, K. Ishikawa, and H. Mori, Bull. Chem. Soc. Jpn., 50, 2406 (1977).

3. S. Ozaki, Y. Watanabe, T. Hoshiko, H. Mizuno, K, Ishikawa, and M. Hori, Chem. Pharm. Bull., 32, 733 (1984).

4. S. Ozaki, Y. Watanabe, T. Ogasawara, Y. Yamauchi, K. Fujiwara, A. Hoshi, and M. Iigo, Chem. Pharm. Bull., 33, 2832 (1985).

5. S. Ozaki, Y. Watanabe, T. Hoshiko, T. Nagase, T. Ogassawara, H. Furukawa, A. Uemura, K. Ishikawa, H. Mori, A. Hoshi, M. Iigo, and R. Tokuzen, Chem. Pharm. Bull., 34, 150 (1986).

6. Y. Koyama, Gan to Kagakuryoho, 7, 1181 (1980); M. Nakanishi, Y. Tsutanishi, T. Nakamura, I. Hashimoto, Y. Sawata, M. Kawai, T. Okuno, S. Fujisawa, and M. Taneda, Yakuri to Chiryo, 8, 1211 (1980), M. Yoshida, H. Murai, and S. Miura, Gan to Kagakuryoho, 7, 1203 (1980).

7. M. Akashi, N. Miyauchi, N. Morita, and T. Minoda, J. Bioactive Compatible Polym., 2, 232 (1987), and references cited therein.

8. S. Ozaki, J. Ohnishi, Y. Watanabe, T. Nohda, T. Nagase, T. Akiyama, N. Uehira, and A. Hoshi, Polym. J., 21, 955 (1989).

9. A. Hoshi, M. Iigo, A. Nakamura, M. Inomata, and K. Kuretani, Chem. Pharm. Bull., 26, 161 (1978). 